\title{
THE BIOLOGY OF LITTORINA LITTOREA \\ PART II. ZONATION IN RELATION TO OTHER GASTROPODS ON STONY AND MUDDY SHORES
}

\author{
By Hilary B. Moore, Ph.D. \\ Biological Station, Bermuda
}

(Text-figs. I-8)

The survey, the results of which are described in this paper, was primarily intended to investigate the zonation of Littorina littorea, but notes have also been included of the zonation of such other gastropod species as occurred with it. The material was collected from the following localities:

Torpoint. 2. x. 36. Just west of the ballast dock at Torpoint, Cornwall. The shore consists of stones, many of them bedded in mud, and thickly overgrown with fucoids. There is little wave-action, but at times a considerable drop in salinity (Hartley \& Spooner, 1938; Milne, 1938).

Drake's Island. 5. viii. 36. On the north side of Drake's Island, in Plymouth Sound. The shore is fairly steep, rocky, and with comparatively little mud. The locality is the same as that used for growth experiments on L. littorea and other species (Moore, 1937, 1938).

Rum Bay. 2. x. I6. On the east side of Plymouth Sound. A stony gully considerably overgrown with fucoids. The lower part of the traverse is probably considerably polluted by a neighbouring sewer.

Wembury. I6. ix. 36. A gulley traversing the reefs near Wembury Point, Devon. The substratum is sand or rock, covered with stones of all sizes. Although the situation is exposed, the rocks on either side of the gulley afford considerable protection from wave-action. This, and to a lesser extent Rum Bay, are the only localities where the zonation levels are likely to be appreciably raised by splash.

Yealm. 2. ix. 36. Misery Point, on the south side of the estuary of the river Yealm, Devon. The substratum is hard mud, covered with stones, which increase in abundance towards the top of the shore, which is dry and very barren. This locality is sheltered from the sea, but subject to considerable tidal currents. It also was used for growth experiments (Moore, I937, 1938).

Caolas Scalpay. I3. vi. 36. About half-way between Broadford Bay and Loch Ainort, Skye, and facing the island of Scalpay. An extremely sheltered shore, but quite free from silt. Growth on the stones showed that even the smallest had not been overturned during the previous winter. 
The method of collecting was to mark out a number of quarter square metre areas at each of a series of levels down the beach. All stones and all free molluscs were then collected from each area, the stones being taken back to the laboratory for examination except at Caolas Scalpay where the examination had to be made in the field. With the same exception all levels were fixed with a dumpy-level and staff, and referred, by means of simultaneous observations of water level at low water on a calm day, to a known level below the Biological Laboratory. At Caolas Scalpay levels were referred to predicted and observed high-water level on a series of days. No great accuracy is therefore claimed for the absolute values of the levels given, especially for the Skye ones.

For the identification of rissoids I am indebted to Dr M. V. Lebour, and for Hydrobia to the Hon. M. Rothschild and Mr R. Winckworth.

\section{Littorina littorea (L.) (Fig. I).}

The lower limit for this species was more uniform than the upper. At all localities it was abundant at mean low water of neap tides, and less so, where sampled, at mean low water of springs. This is in agreement with the levels given by Orton (1929) - present at mean low water, less at mean low-water springs; by Gowanloch \& Hayes (1926)-lowest low-tide level; and by Colman (I933)-mean to equinoctial low-water springs; but Huntsman (I9I8) says that, while only intertidal at St Andrews, they extend down to 20 fathoms at Chitticamp.

The upper limit seems to depend considerably on local conditions. At the Yealm, where the upper beach was stony, with little algal growth, they hardly passed mean low-water neaps. At the other localities they attained equinoctial high-water neaps in some abundance, and a few stragglers occurred even higher. Orton gives the upper limit as between mid-tide and mean high-water neaps; Gowanloch \& Hayes as mean high water; and Colman as lowest mean high-water neaps. L. littorea thus seems to require wetting by the sea every tide, and in the localities where it occurs above high-water neaps the effective levels are raised by splash. The question of the effect of age on zonation in this species is discussed later in the paper.

\section{Littorina rudis (Maton) (Fig. 2).}

In contrast with $L$. littorea, this species has a well-defined upper, and a much more variable lower limit. At three localities the upper limit was about mean high-water springs and at the other two about equinoctial high-water

Fig. I. Vertical distribution of Littorina littorea (numbers per square metre). Vertical heights are shown in metres above and below mean sea level. I=high water of equinoctial spring tides. II $=$ mean high water of spring tides. III $=$ mean high water of neap tides. $\mathrm{IV}=$ high water of equinoctial neap tides. $\mathrm{V}=$ mean sea-level. $\mathrm{VI}=$ low water of equinoctial neap tides. VII $=$ mean low water of neap tides. VIII $=$ mean low water of spring tides. IX $=$ low water of equinoctial spring tides. Localities: $a$, Torpoint; $b$, Drake's Island; $c$, Rum Bay; $d$, Wembury; $e$, Yealm; $f$, Caolas Scalpay.

Fig. 2. Vertical distribution of Littorina rudis. Symbols as in Fig. I. 


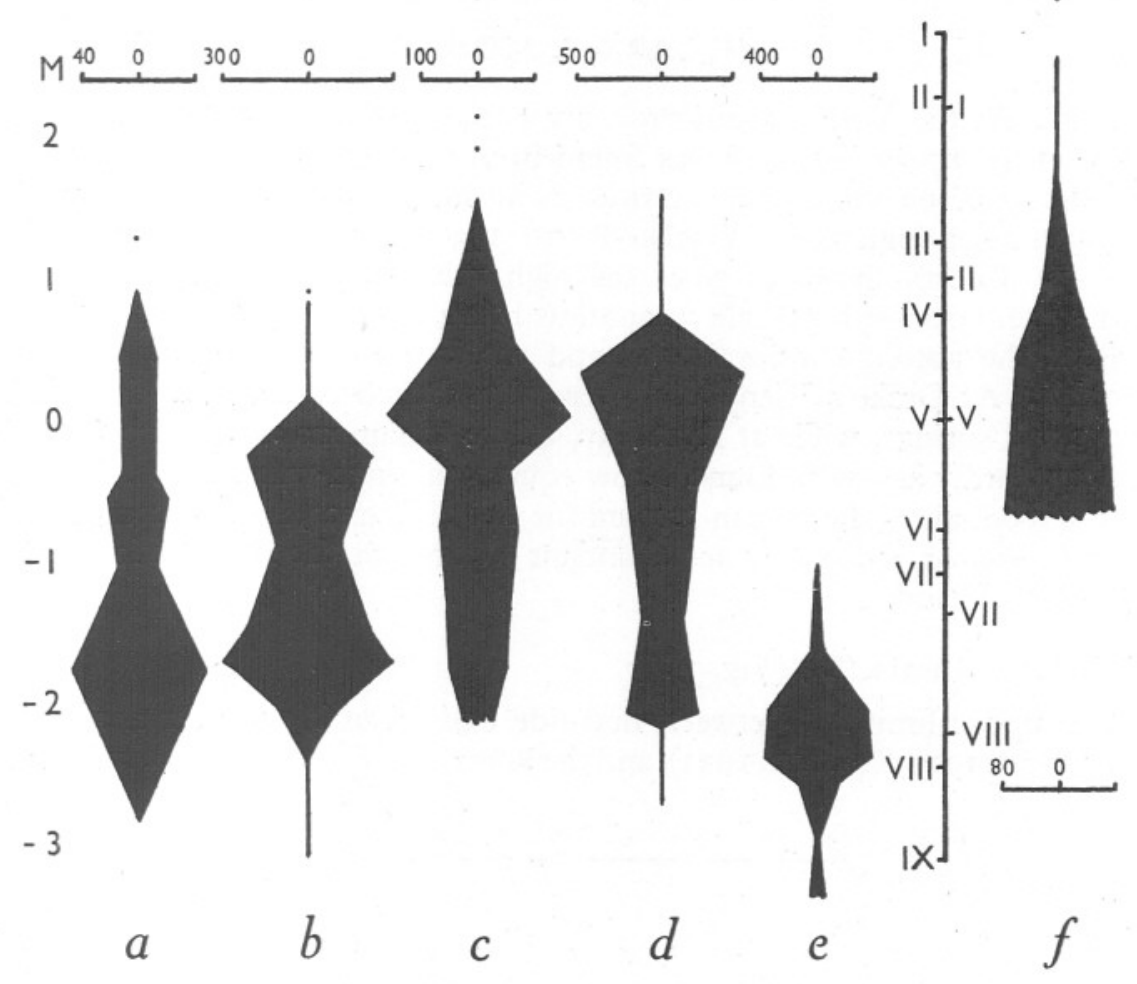

Fig. I.

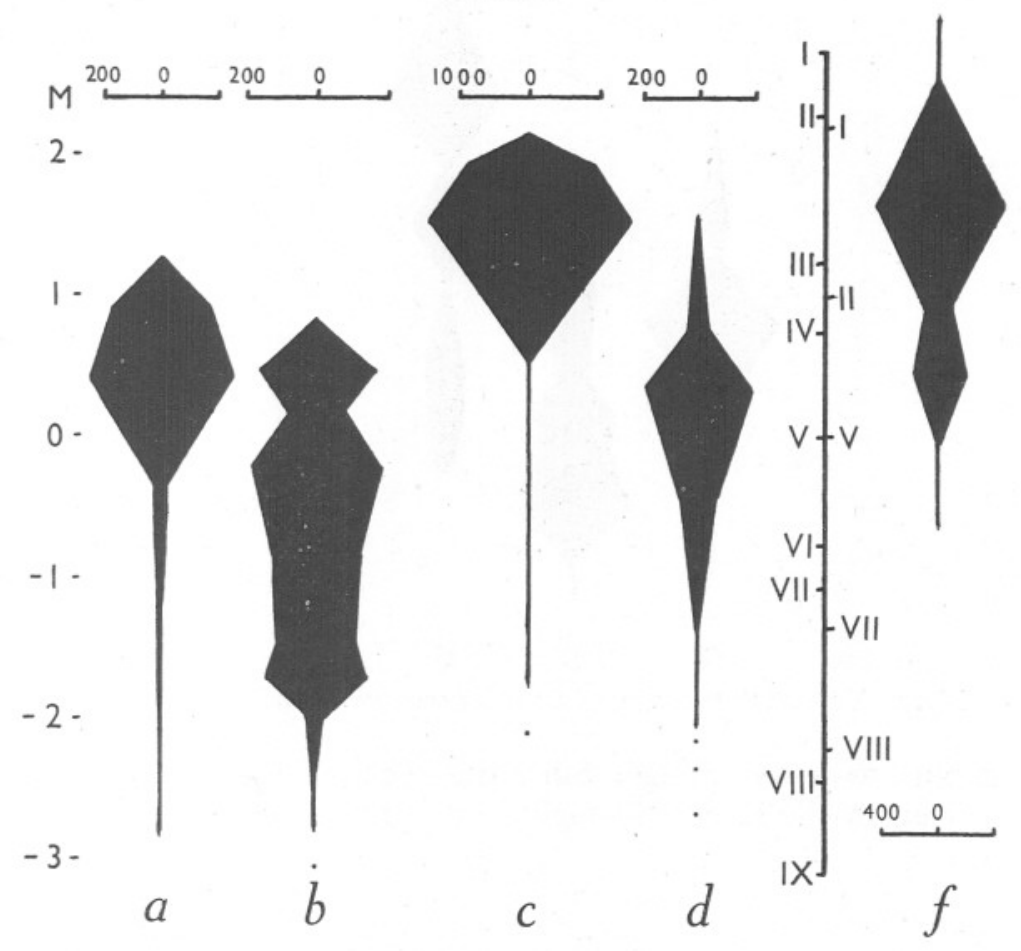

Fig. 2. 
springs. At the Yealm, again probably because of the dryness and lack of algae in the upper levels, it was found in very small numbers only. Other authors agree on these levels: Orton, mean high-water springs; Gowanloch \& Hayes mean high water; Fischer-Piette (1936) just above mean high-water springs. Colman however gives the high value of $3 \mathrm{ft}$. above equinoctial high-water springs, his locality doubtless being more affected by splash.

Both the absolute lower limits, and the limits of abundance, are very variable. At Drake's Island they were abundant between mean low-water neaps and springs, while at Rum Bay, where conditions are apparently very similar, hardly any were found below equinoctial high-water neaps. Neither lack of food nor of shelter can account for this difference, nor can competition with $L$. littorea, since they are abundant along with the latter at low levels at Drake's Island.

Littorina obtusata (L.) (Fig. 3).

The upper limit lies between mid-tide and mean high-water neaps (see also Orton, 1929; Colman, 1933), and the lower limit, at any rate of abundance,

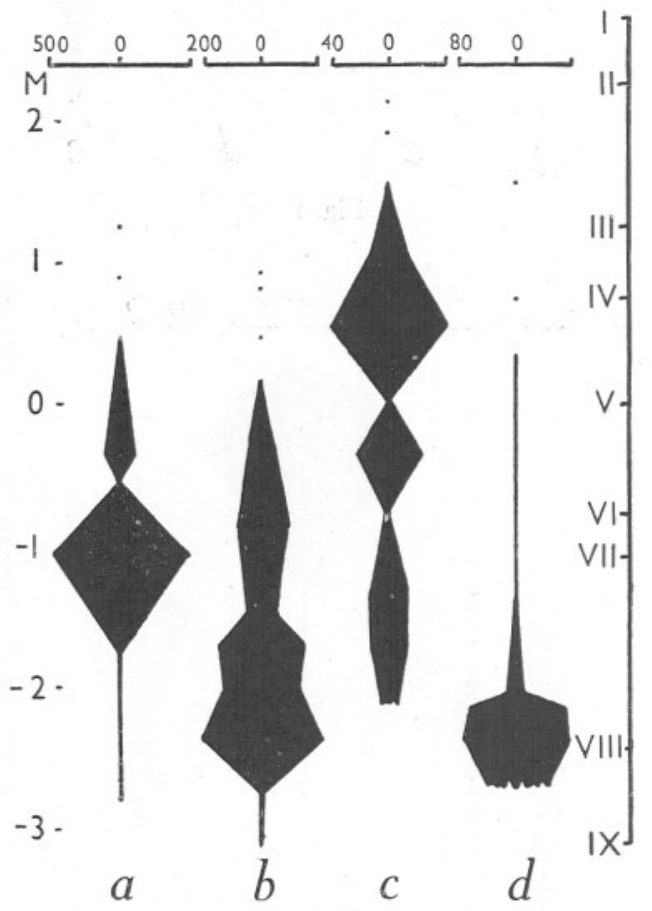

Fig. 3. Vertical distribution of Littorina obtusata. Symbols as in Fig. I.

about mean low-water springs. Since this species is far more abundant on fucoids than on the stones themselves, it is not surprising that it was not 
found at the Yealm where fucoids were so scarce. At Caolas Scalpay also it was present only in very small numbers round low water.

Hydrobia ulvae (Penn.) (Fig. 4).

This is not typically a rocky shore gastropod, occurring in far greater numbers on estuarine saltings and mud flats. The level of the former is usually above high-water neaps, and H. ulvae may be extraordinarily abundant on them. Its frequent absence at low water on estuarine mud flats is probably due in many instances to strong tidal action. It is interesting therefore to

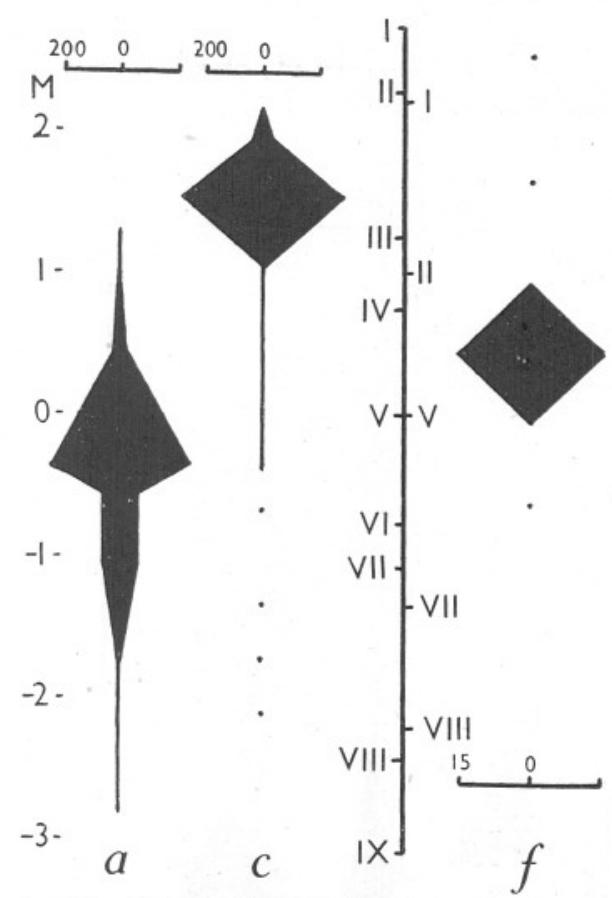

Fig. 4. Vertical distribution of Hydrobia ulvae. Symbols as in Fig. I.

note its occurrence in small numbers below mean low-water springs at Torpoint where the shore combines muddiness with protection by fucoids and stones. It is also interesting that at Caolas Scalpay, where the shore was strikingly free from silt, the Hydrobia were confined to a very limited zone round mid-tide.

Alvania crassa (Kanmacher), Rissoa parva (da Costa), Cingula semicostata (Mont.), Barleeia unifasciata (Mont.).

All recorded from mean low-water spring tide at Wembury and not elsewhere. 
Cingula cingillus (Mont.).

A few at Rum Bay from mean high-water neaps to mean low-water neaps, and at Wembury from mean low-water neaps to mean low-water springs.

Osilinus lineatus (da Costa).

Found only at Wembury, from mean high-water neaps to mean low-water neaps. Colman records it from mean high-water neaps to mid-tide, but it is known to extend lower under the influence of fresh water.

Gibbula cineraria (L.) (Fig. 5).

Except at Caolas Scalpay, this did not occur in any numbers above mean low-water neaps, and was never found above mid-tide. At most localities

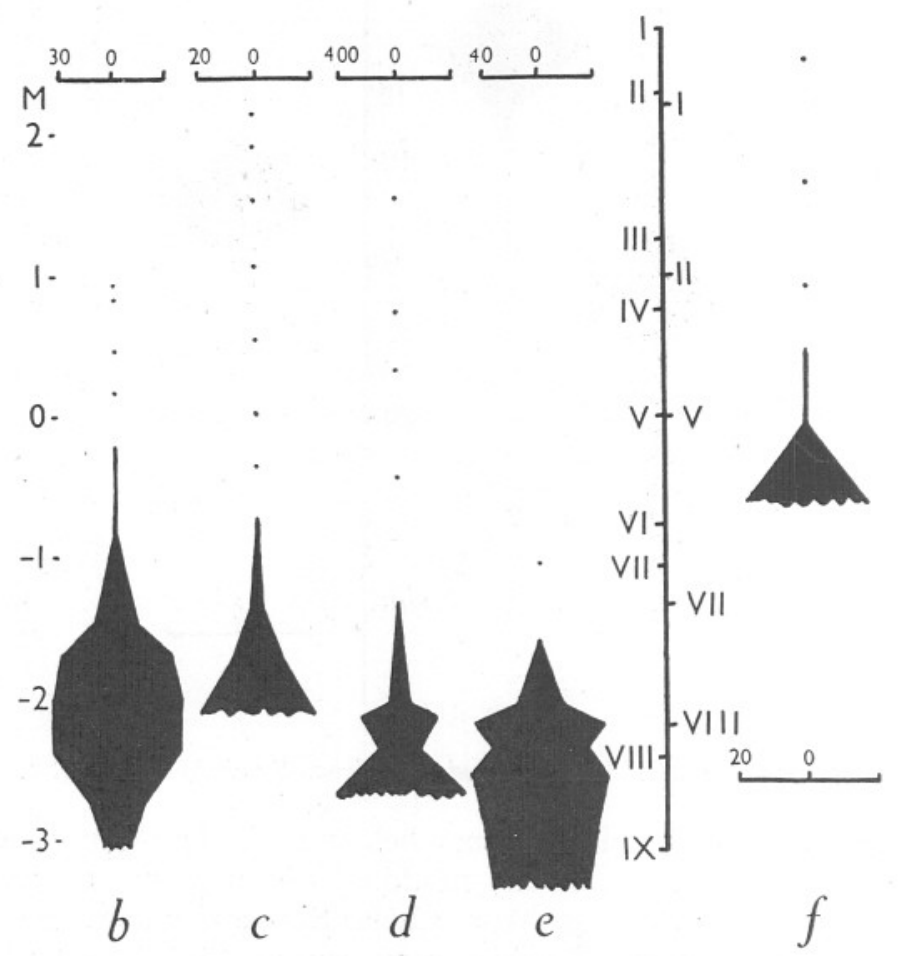

Fig. 5. Vertical distribution of Gibbula cineraria. Symbols as in Fig. I.

the level of maximum abundance seemed to be below the lowest level sampled. For the Isle of Man it is recorded from low water to I 5 fathoms, and more rarely deeper (Moore, 1937a), and in the Plymouth Fauna (Marine Biological Association, I93I) down to Io fathoms. 
Gibbula umbilicalis (da Costa) (Fig. 6).

A few above mid-tide, but maximum numbers between mean low-water neaps and mean low-water springs, and few or none below low water. This species does not usually extend so far below low water as the preceding: Plymouth Fauna, down to 3 fathoms; Moore, never below low water: and most authors record it as extending to a higher level on the shore than G. cineraria. The Plymouth Fauna gives its upper limit as high water; Moore, for the Isle of Man, as mid-tide, and Dolfus (I9I4) even gives its lower limit

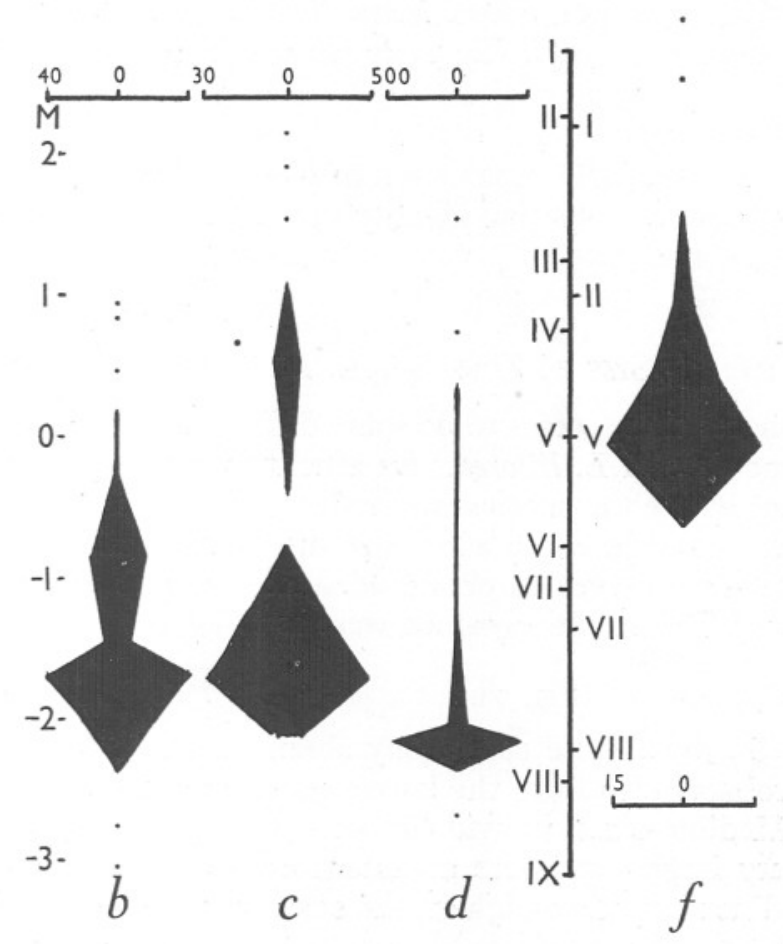

Fig. 6. Vertical distribution of Gibbula umbilicalis. Symbols as in Fig. I.

as the upper limit of $G$. cineraria. Our localities, however, suggest that, while stragglers were certainly found a lot higher than any $G$. cineraria, the zones of maximum abundance showed less difference.

Buccinum undatum L.

A few young individuals were found about mean low-water springs at the Yealm. Gowanloch (1927) has discussed in detail the unfitness of this species for intertidal life. 
Purpura lapillus L.

The zonation of this species has been discussed already in another paper (Moore, I938).

Nassarius reticulatus (L.).

At Rum Bay and the Yealm, from between mid-tide and mean low-water neaps down to below low water.

Calyptraea chinensis (L.).

At the Yealm from just above mean low-water springs to just below equinoctial low-water springs. Up to 40 per square metre.

Patella spp.

As these are not typically inhabitants of loose stones, and as there is still considerable doubt as to specific identity in the British Patella spp., the few found were not counted.

\section{ReLATion of Size to Zonation In LITTORINA LITTOREA}

On many shores there seems to be some difference in vertical distribution in the different sizes of $L$. littorea. An attempt was therefore made at four of the localities where the species was sufficiently abundant, to collect large enough samples at all levels to allow size distribution analyses to be made. It proved difficult however to obtain adequate samples towards the upper and lower limits. The results obtained were as follows:

Drake's Island, 5. viii. 36 (Fig. 7).

Young (1936 brood) were completely absent from the upper part of the range, and probably also from the lowest part (sample too small to include in Fig. 7). Medium-sized individuals were present throughout the entire range, but very large ones were abundant only at the middle and lowest levels, and did not extend so high on the beach as the medium ones.

Wembury, I6. ix. 36 (Fig. 7).

Young (I936 brood) were present at all levels, though more abundant (relative to adults) round the centre of their range. Very large individuals, as at Drake's Island, were confined to the middle and bottom of their range.

Yealm, 2. ix. 36 (Fig. 8).

Young (1936 brood) were rare in the lowest levels, and large individuals absent from the highest. If the numbers are to be considered adequate, which seems rather doubtful, there is a suggestion of greater growth rate in the first year towards high water. This is interesting when compared with 


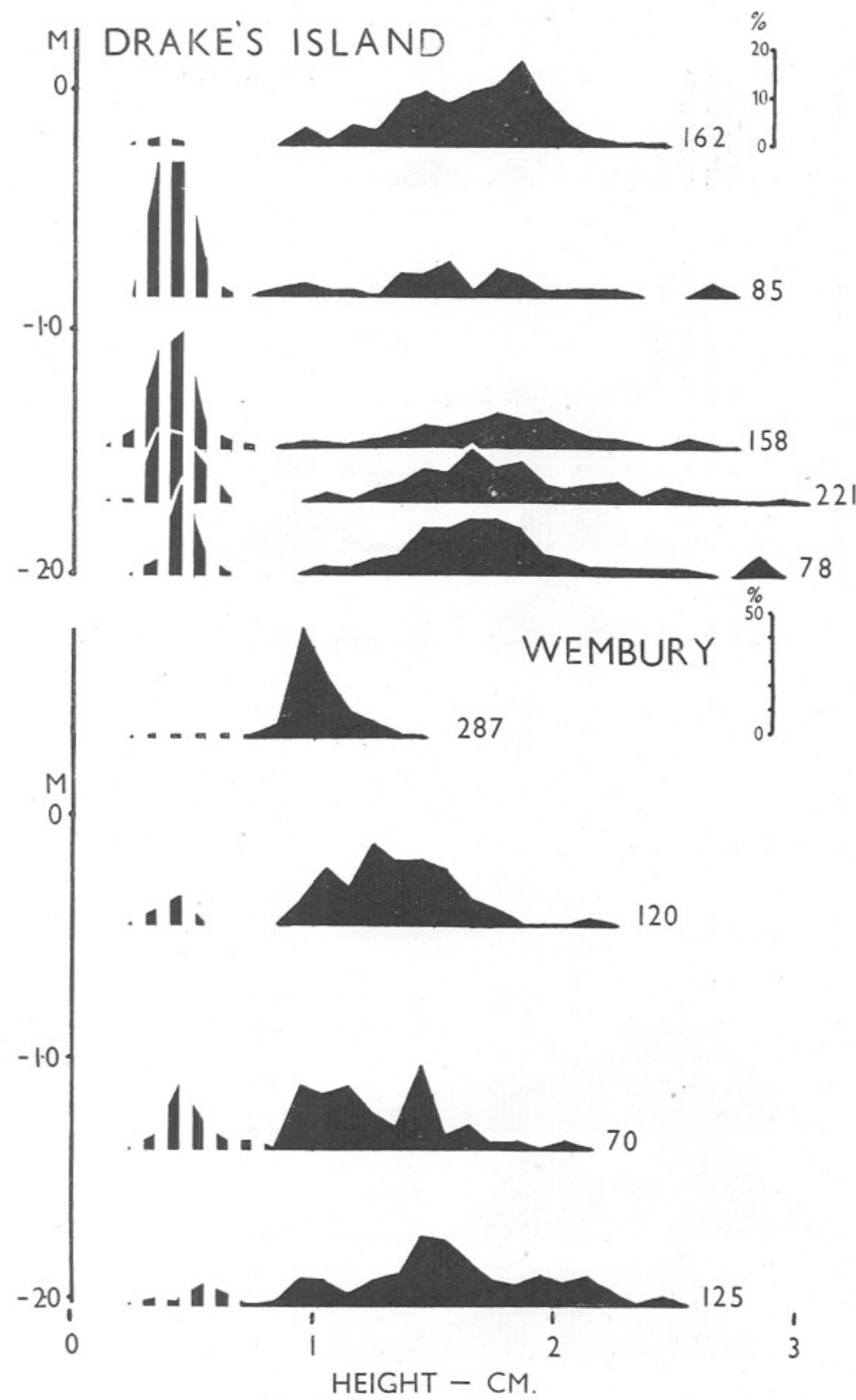

Fig. 7. Size distribution of Littorina littorea in relation to tidal level at Drake's Island and Wembury. Heights of shells are measured in centimetres and the numbers of shells measured in each sample are shown by the figures at the right of each graph. For each locality, all samples are drawn to the percentage scale shown, except in the case of the top sample from Wembury, which is drawn to half-scale. The extent of the 1936 group is indicated by vertical hatching. 

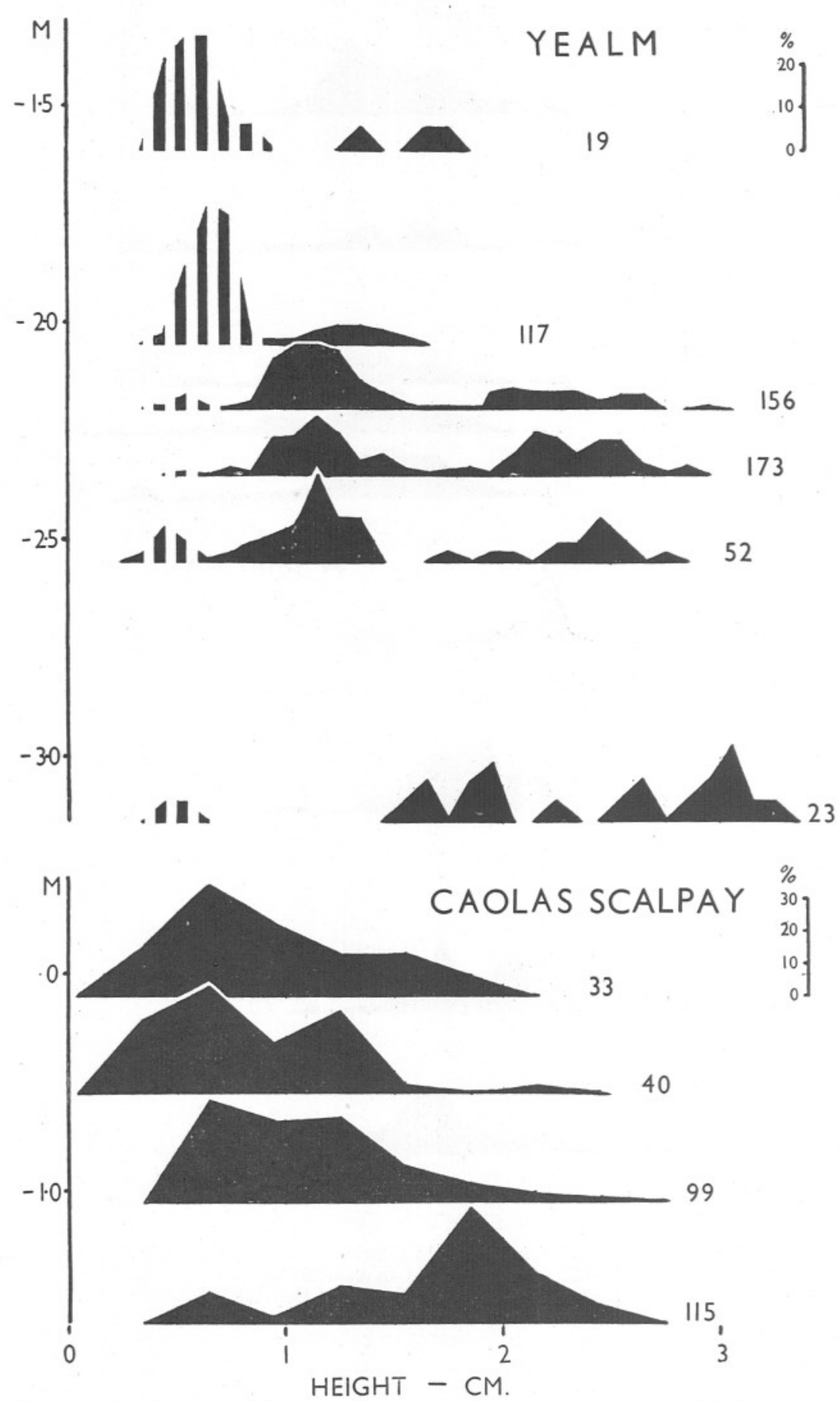

Fig. 8. Size distribution of Littorina littorea in relation to tidal level at Yealm and Caolas Scalpay. Symbols as in Fig. 7. The 1936 group is not indicated at Caolas Scalpay as the material was collected there too early in the year for the new brood to have settled. 
Hayes's (1929) statement that at St Andrews the growth rate of young L. littorea is greatest towards low water. It may be noted that the rate of growth at the Yealm was considerably less at all sizes than at Drake's Island (Moore, I937).

Caolas Scalpay, II-I8. vi. 36.

Young (probably I935, as I936 brood were unlikely to have settled yet), scarce, but not absent, towards the bottom of their range, and large ones similarly scarce towards the top.

The general result, then, from this admittedly small number of localities, is that medium-sized individuals occur throughout the local vertical range of the species; the largest individuals tend to be rare or absent at the top levels, and may be most abundant at the lowest levels. Very young individuals, on the other hand, tend to be scarce or absent in the lowest levels, and more rarely in the highest levels also.

\section{REFERENCES}

Colman, J., I933. The nature of the intertidal zonation of plants and animals. Fourn. Mar. Biol. Assoc., Vol. xviII, pp. 435-76.

Dolfus, M. R., I9I4. Les zones subterrestre et littorales à l'île Tatihou et dans la région de Saint-Vaast-la-Hougue (Manche). Bull. Mus. Nat. Hist. Paris, Tome 20, pp. 253-67.

FisCHER-PIETTE, E., I936. Études sur la biogéography intercotidale des deux rives de la Manche. Fourn. Linn. Soc. London, Zool., Vol. 40, pp. I8I-272.

GowANLOCH, J. N., I927. Contribution to the study of marine gastropods. II. The intertidal life of Buccinum undatum, a study in non-adaptation. Contrib. Canad. Biol. Fish., Vol. 3, pp. 167-77.

GowANLOCH, J. N. \& HAYES, F. R., I926. Idem. I. The physical factors, behaviour and intertidal life of Littorina. Contrib. Canad. Biol. Fish., Vol. 3, pp. 135-65.

Hartley, P. H. T. \& SPooner, G. M., I938. The ecology of the Tamar estuary. I. Introduction. Fourn. Mar. Biol. Assoc., Vol. xxII, pp. 50I-8.

HAYES, F. R., I929. Contribution to the study of marine gastropods. III. Development, growth and behaviour of Littorina. Contrib. Canad. Biol. Fish., Vol. 4, pp. 4I3-30.

Huntsman, A. G., I9I8. The vertical distribution of certain intertidal animals. Trans. Roy. Soc. Canada, Vol. I2, pp. 53-60.

Marine Biological Association, i93i. Plymouth Marine Fauna, pp. I-37i.

MILNE, A., I938. The ecology of the Tamar estuary. III. Salinity and temperature conditions in the lower estuary. Fourn. Mar. Biol. Assoc., Vol. xxII, pp. 529-42.

Moore, H. B., I937. The biology of Littorina littorea. Part I. Growth of the shell and tissues, spawning, length of life and mortality. Fourn. Mar. Biol. Assoc., Vol. XxI, pp. $72 \mathrm{I}-42$.

- I937 a. Marine fauna of the Isle of Man, pp. I-293. University Press, Liverpool. I938. The biology of Purpura lapillus. Part II. Growth. Part III. Life history and relation to environmental factors. Fourn. Mar. Biol. Assoc., Vol. xxiII, pp. $57-74$.

Orton, J. H., 1929. Observations on Patella vulgata. Part III. Habitat and habits. fourn. Mar. Biol. Assoc., Vol. xvi, pp. 277-88. 